\title{
NEW BIOLOGICAL DATA FOR SALARIA FLUVIATILIS (ASSO, 1801) (BLENNIIDAE) FROM NORTH OF ALGERIA
}

\author{
Djamel Amalou*, Djamila Ider, Zouhir Ramdane and Riadh Moulaï
}

Laboratoire de Zoologie Appliquée et d'Ecophysiologie Animale, Faculté des Sciences de la Nature et de la Vie, Université A. Mira de Bejaia, 06000 Bejaia, Algérie

*Corresponding author. Email: amalou_djamel@yahoo.fr

\section{Article history}

Received: 30 April 2020; accepted 12 August 2020

\section{Keywords:}

Salaria fluviatilis; age; growth parameters; reproduction period; Kabylie region

\begin{abstract}
The family Blenniidae inhabiting freshwater systems has been scarcely studied, particularly in North Africa. The present study focused on the biology of Salaria fluviatilis (Asso, 1801) from Kabylie region (northern Algeria). A total of 198 specimens were sampled from May 2015 to May 2016. The total length of this fish varied between 4.9 and $12.7 \mathrm{~cm}$ and its total weight varied between 1.2 and $23.7 \mathrm{~g}$. The age of this fish species varied between 1 and 3 years. The sex ratio of $S$. fluviatilis was in balance ( $\mathrm{SR}=0.98)$. The results of our investigation of length-weight relationship show highly significant correlation $(p>0.001)$; the correlation coefficient $r$ varied between 0.966 and 0.985 . The specimens of this fish species exhibited positive allometry in males $(b=3.195)$ and negative allometry in females $(b=2.782)$. Growth parameters were higher in males than in females, except for the growth rate $(\mathrm{K})$ where the values were close. The growth performance index $(\Phi)$ was similar in both sexes, which confirms the same growth potential for males and females. In Kabylie region, the breeding period of S. fluviatilis occurred between April and July. Our results of analysis of the hepatosomatic index (HSI) and Fulton's K show that liver energy reserves are not devoted for reproduction; however, muscle reserves seem to support this physiological activity. In perspective, more biological studies must be carried out on this rare and poorly studied fish.
\end{abstract}

\section{INTRODUCTION}

Fishes inhabiting freshwater systems are numerous and various. They comprise several families. Among them, the Blenniidae forms a large family of marine origin belonging to the order of Perciformes and suborder of Blennoides. It includes some 345 species of small benthic fish (Gharred and Ktari 2001). Of these, the fluvial blenny, Salaria fluviatilis (Asso, 1801), has long been considered the only freshwater representative of Blenniidae (Perdices et al. 2000; Almada et al. 2001, 2005; Neat et al. 2003; Briggs 2010). Recently, two other species of this family have been described: Salaria economidisi Kottelat 2004, endemic to Lake Trichonis in Greece (Kottelat 2004) and Salaria atlantica Doadrio, Perea and Yahyaoui 2011, endemic to the Sebou basin in Morocco (Doadrio et al. 2011).

Salaria fluviatilis is a benthic fish from the Mediterranean and the Black Sea (Zander 1972; Kottelat and Freyhof 2007; Laporte and Magnan 2010; Persat 2011). Populations of this freshwater fish have also been found on the Atlantic coast of Morocco (Doadrio et al. 2011). This species generally inhabits small rivers and lakes (Changeux and Pont 1995; Côté et al. 1999; Neat et al. 2003; Vinyoles and De Sostoa 2007). It is a species that lives in small localized populations. Adults can survive a wide range of habitats but with some preference for deep fast flowing areas and a substrate dominated by rocks, stones and gravel; to spawn, they prefer quiet areas (Freeman et al. 1990; Bianco 1995; Elvira 1995a; Côté et al. 1999, Keith and Allardi 2001; Roché 2001; Kottelat and Freyhof 2007).

This species is characterized by a greenish brown body without scales and compressed laterally on the back; its flanks are often mottled with black (Roché 2001; Keith and Allardi 2001; Azeroual 2003). It has long dorsal and ventral fins. Pelvic fins are hook-shaped. Jaws are powerful and have pointed teeth. S. fluviatilis is characterized by sexual dimorphism where males differ from females by the presence of a ridge and a pair of annular glands (Roché 2001; Keith et al. 2011; Persat 2011; Laporte et al. 2018).

S. fluviatilis is considered to be a highly vulnerable species. It is in danger of extension in most northern Mediterranean countries: Croatia (Mrakovcic et al. 1995), Italy (Bianco 1995), Spain (Elvira 1995a; Doadrio 2001), France (Changeux and Pont 1995; Keith and Allardi 2001; UICN and Onema 2010), Greece (Economidis 1995), and Turkey (Balik 1995).

According to Côté et al. (1999), S. fluviatilis has a considerable biogeographic and conservation interest due to its circum-Mediterranean distribution. In addition, this species is very sensitive to anthropogenic water pollution (Ferrito and Tigano 1996; Hernández et al. 2000; Aparicio et al. 2000), substrate alterations (Côté et al. 
1999) and severe droughts (Vinyoles and De Sostoa 2007), which make it a good bioindicator of aquatic environment quality (Laporte et al. 2011).

Several studies have been conducted on the species' distribution and conservation status (Bianco 1995; Elvira 1995; Changeux and Pont 1995; Hernández et al. 2000; Alp and Kara 2007; Laporte and Magnan 2010), habitat and ecological requirements (Côté et al. 1999; Freeman et al. 1990), reproduction and population dynamics (Vinyoles et al. 2002; Vinyoles and De Sostoa 2007; Gasith and Goren 2009), embryonic development (Gil et al. 2010), behaviour and morphology (Neat et al. 2003), and genetic structure Laporte et al. 2015a).

In spite of the existence of an important hydrographic ecosystem hosting several species of fish (Bacha and Amara 2007; Kara 2011; Lounaci-Daoudi et al. 2016) and despite conservation and ecological importance of S. fluviatilis (bio-indication), few studies on populations of this fish, particularly on its growth and reproduction parameters, have been undertaken in Algeria. This is probably true for the whole Mediterranean basin. The aim of our research was to study some biological aspects of S. fluviatilis from Kabylie region (northern Algeria) and to provide scientific data that could play an important role in its conservation.

\section{MATERIALS AND METHODS}

\section{Study area}

The present study was carried out in Kabylie region (Figure 1). It is one of the largest coastal areas in Algeria $\left(3261 \mathrm{~km}^{2}\right)$. It is located between $36^{\circ} 15^{\prime}$ and $36^{\circ} 55^{\prime}$ north latitudes and $4^{\circ} 20^{\prime}$ and $5^{\circ} 30^{\prime}$ east longitudes. It opens to the Mediterranean Sea on a seafront of more than $100 \mathrm{~km}$. The study area has several rivers draining water into the sea. The most important of them are: Aguerioune, Zitouna, Djemaa, Boussellam, Sahel. oued Dass, Acif el Hammam, and Soummam (Anonymous 1980) (Figure 1).

From May 2015 to May 2016, a total of 198 specimens of $S$. fluviatilis were captured using a hawk net. Sampling was carried out in 3 different rivers: Aguerioune, Boulezzazen, and Djemaa (Figure 1). Once the fish were returned to the laboratory, each specimen was measured (total length (TL), total weight (TW), eviscerated weight (EW), liver weight (LW), and gonad weight (GW)). The age was determined by otolithometry. The sex of each individual was determined after dissection and observation of gonads.

\section{Study of growth parameters}

The relationship between total length and total weight is represented by the equation $\mathrm{TW}^{-}=\mathrm{a} \cdot \mathrm{TL}^{\mathbf{b}}(\mathrm{Le}$ Cren 1951; Ricker 1975), where TW is total fresh weight of the fish $(\mathrm{g})$, TL is total length of the fish $(\mathrm{cm})$, a is constant, and $\mathrm{b}$ is coefficient of allometry.

The coefficient $b$ is a characteristic factor of the environment and of the development phase of the fish species (Mayrat 1970). It corresponds to the slope of the regression line and varies between 2 and 4, but it is often close to 3 . Its value defines 3 types of allometry: when $b=3$, the growth is said to be isometric (weight and length grow proportionally), and when $b$ is different from 3 , growth is allometric: if $b>3$, fish grows in weight more than in length (major or positive

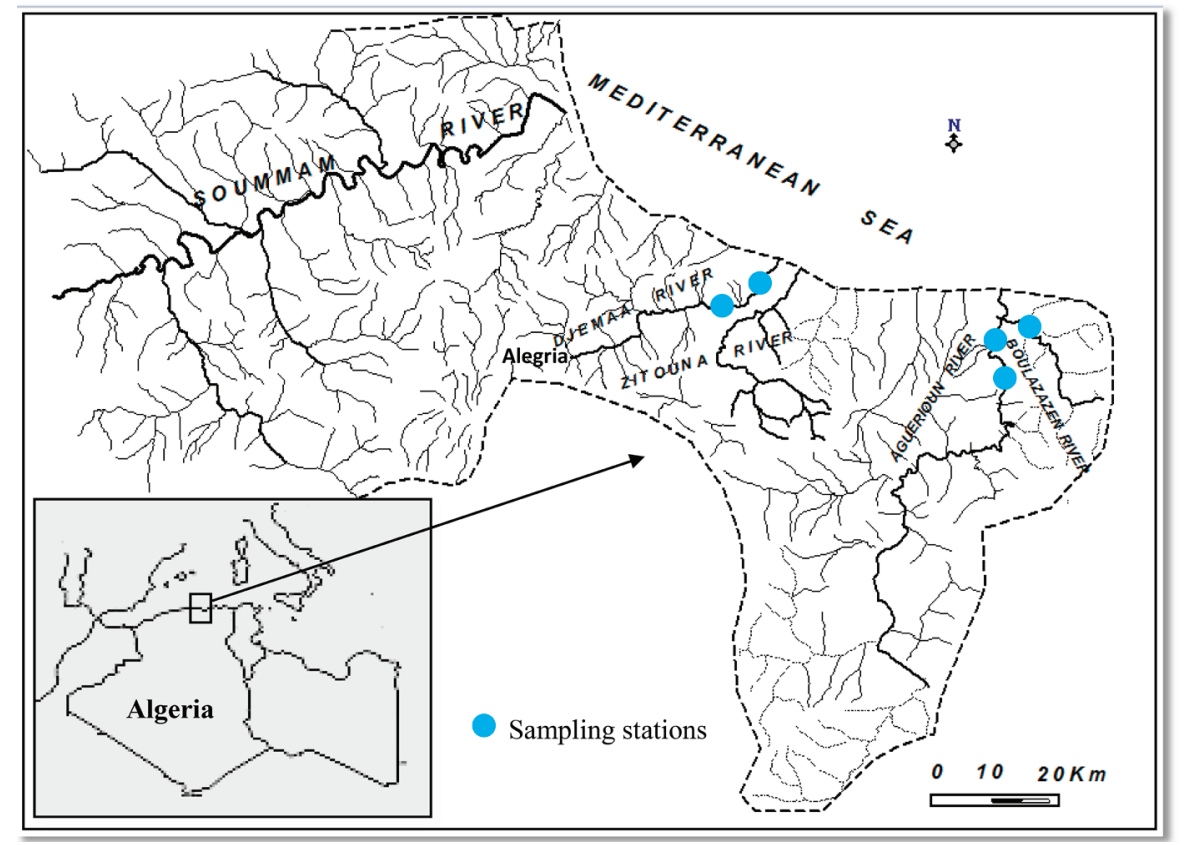

Figure 1. Localization and sampling area (Kabylie region). 
allometry), and if $\mathrm{b}<3$, fish grows in length more than in weight (diminishing or negative allometry) (Micha 1973; Ricker 1980). Length-weight relationship was determined using FISHPARM software.

To check if the value of allometric coefficient $b$ obtained from regression curves is different from 3 , this value is statistically compared to $\mathrm{b}_{0}=3$ using Student's $t$-test at $\alpha=0.05$ (Dagnelie 1975):

$$
t_{o b s}=\frac{\left(\left|b^{2}-b_{0}^{2}\right| \sqrt{n-2}\right)}{\left(2 b_{0} \cdot b \sqrt{1-r^{2}}\right)},
$$

where $t_{o b s}$ is $t$ observed, $b$ is allometric coefficient (slope), $b_{0}$ is theoretical slope $\left(b_{0}=3\right), n$ is the number of data pairs, and $r$ is correlation coefficient.

The value of $t_{o b s}$ is compared to that of theoretical " $t "=t_{1-\alpha / 2}$ (according to Student's table) or $\alpha=0.05$. Thus, two cases can occur:

-If $t_{o b s} \leq$ theoretical $t$, the difference is not significant, and $b=3$ (isometry).

-If $t_{o b s}>$ theoretical $t$ : we reject the hypothesis, the difference is significant (allometry), and two cases can occur: if $b>3$, there is a major or positive allometry, and if $b$ $<3$, there is a diminishing or negative allometry.

For a study of the linear growth of $S$. fluviatilis, we applied the model of Von Bertalanffy (1938):

$$
\mathrm{TL}=\mathrm{L} \infty\left(1-\mathrm{e}^{-\mathrm{K}(\mathrm{t}-\mathrm{to})}\right),
$$

where TL is the total length of the fish at time $t, L \infty$ is the maximum or asymptotic length (theoretically it is the length that the fish would reach if it were to live and grow indefinitely), $\mathrm{K}$ is the growth coefficient determining the speed at which the fish reaches its maximum size, $t_{o}$ is the theoretical age where length and weight are zero. The value of $t_{o}$ has no biological significance, so it is zero $\left(t_{o}=0\right)$ (Knight 1968).

Growth parameters were determined using two programs: Fishparm (Prager et al. 1994) and Fisat II version 1.2.0 software (Gayanilo et al. 2005). The age-length key for both sexes was estimated using indirect methods by D’Arcy Thompson (1948) and Bhattacharya (1967) and Fisat II version 1.2.0 software. Indirect methods (mathematical expression) based on size frequency distribution (polymodal frequency distribution) were applied to confirm our results of direct methods (otolithometry).

A study of growth performance $\Phi$ (cm.year ${ }^{-1}$, Pauly and Munro 1984) allows a comparison of growth performance between different populations of this species in the same region or in different regions. It is calculated as follows:

$$
\Phi=\log (\mathrm{K})+2 \log (\mathrm{L} \infty)
$$

where $\mathrm{K}$ and $\mathrm{L} \infty$ are parameters of the Von Bertalanffy equation.

Fulton's coefficient $(\mathrm{K})$ is used to estimate seasonal changes in overweight under the influence of external (medium) or internal (physiological) factors. It is considered a good indicator of the nutritional status and the state of energy reserves of a fish. It can be calculated by the following formula (Tesch 1971; Sutton et al. 2000):

$$
\mathrm{K}=\left(\mathrm{EW} / \mathrm{TL}^{3}\right) \times 100,
$$

where $\mathrm{K}$ is Fulton's coefficient of condition, EW is eviscerated weight, and TL is total length.

\section{Study of reproduction parameters}

The sex ratio (SR) reflects the rate of masculinity or femininity whose variations are sometimes related to the environment (Kartas and Quignard 1984). The numerical proportions of sexes are expressed as follows:

$\mathrm{SR}=\mathrm{Nm} / \mathrm{Nf}$ (the ratio of the number of male specimens to the number of female specimens),

masculinity rate: $(\mathrm{Nm} / \mathrm{Nm}+\mathrm{Nf}) \times 100$,

femininity rate: $(\mathrm{Nf} / \mathrm{Nm}+\mathrm{Nf}) \times 100$,

where SR is sex ratio, $\mathrm{Nm}$ is the number of male specimens, and $\mathrm{Nf}$ is the number of female specimens.

To determine the reproductive period of $S$. fluviatilis in the study region, the evolution of the gonadosomatic index (GSI) was analyzed (Bougis 1952). The evolution of the hepatosomatic index (HSI) was also analyzed in order to verify whether the energy required for the maturation of gonads comes from the lipid reserves stored in the liver. The evolution of Fulton's K index was observed to check the contribution of the muscle to the reproduction physiology:

$\mathrm{GSI}=(\mathrm{GW} / \mathrm{EW}) \times 100$,

$\mathrm{HSI}=(\mathrm{LW} / \mathrm{EW}) \times 100$,

where GW is the weight of gonads, LW is the weight of the liver, and EW is eviscerated weight.

\section{Statistical analysis}

The statistical analysis of our data was carried out using the Statistica 5.1 software. To compare total lengths and total weights between male and female specimens, we used Student's $t$-test. The Chi-square test $\left(\chi^{2}\right)$ was used to compare percentages (masculinity and femininity rates). To compare changes in the condition coefficient (Fulton's K) according to sex, age classes and size classes, we opted for one-way analysis of variance (ANOVA). 


\section{RESULTS}

Identification of sexual dimorphism in S. fluviatilis

The examined specimens of $S$. fluviatilis exhibited a remarkable sexual dimorphism, where adult males differed from females by the presence of a ridge on the head and a pair of papillae in front of the anal fin (see black arrows in Figure 2a, b).
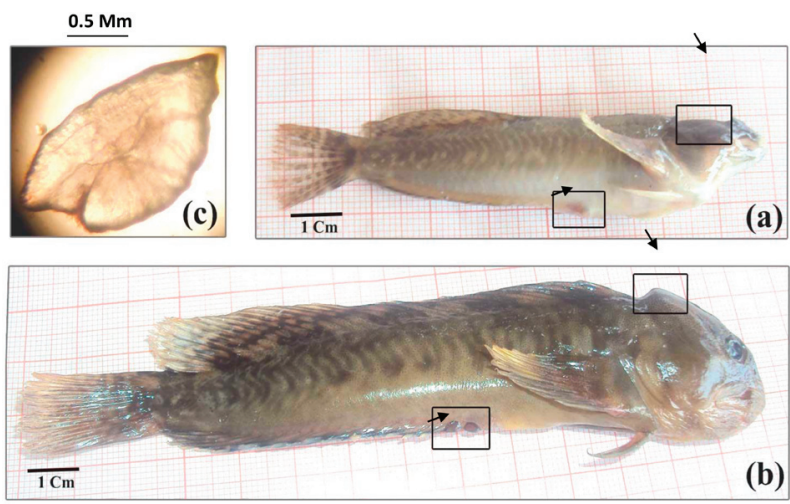

Figure 2. Photo of Salaria fluviatilis. a: Female; b: Male; c: Otolith morphology.

\section{Demographic structure}

The examined specimens of $S$. fluviatilis $(\mathrm{n}=198)$ included 100 females and 98 males. The total length (TL) varied between 4.9 and $12.7 \mathrm{~cm}$ (mean length $=8.8 \mathrm{~cm})$. The total weight $(\mathrm{TW})$ varied between 1.2 and $23.7 \mathrm{~g}$ (mean weight $=12.45 \mathrm{~g}$ ). The age varied between 1 and 3 years. These results show very high variations (Student's $t$-test, $p<0.001$ ) in different size classes and also in different weight classes for both sexes (Table 1).

Table 1. Variation of total length and total weight in Salaria fluviatilis in the study region.

\begin{tabular}{|l|c|c|c|}
\hline & Females & Males & $P$ \\
\hline Total length $(\mathrm{cm})$ & {$[4.9-10.4]$} & {$[5.2-12.7]$} & $(p<0.001)$ \\
\hline Total weight $(\mathrm{g})$ & {$[1.2-12.1]$} & {$[1.3-23.7]$} & $(p<0.001)$ \\
\hline
\end{tabular}

The examined fish specimens whose size varied between 6 and $8 \mathrm{~cm}$ were best represented ( 91 specimens), while specimens whose total length was more than $12 \mathrm{~cm}$ were less represented ( 2 specimens). Female specimens whose size varied between 6 and $8 \mathrm{~cm}$ dominated with 58 specimens, while females whose size was greater than $10 \mathrm{~cm}$ were represented by only one specimen. Male specimens whose size varied between 8 and 10 $\mathrm{cm}$ were well represented (Figure 3a, b, c).

Our results show that two-year-old specimens were best represented in the whole population, in females, and in males $(85,47$, and 38 specimens, respectively). However, three-year-old specimens of $S$. fluviatilis
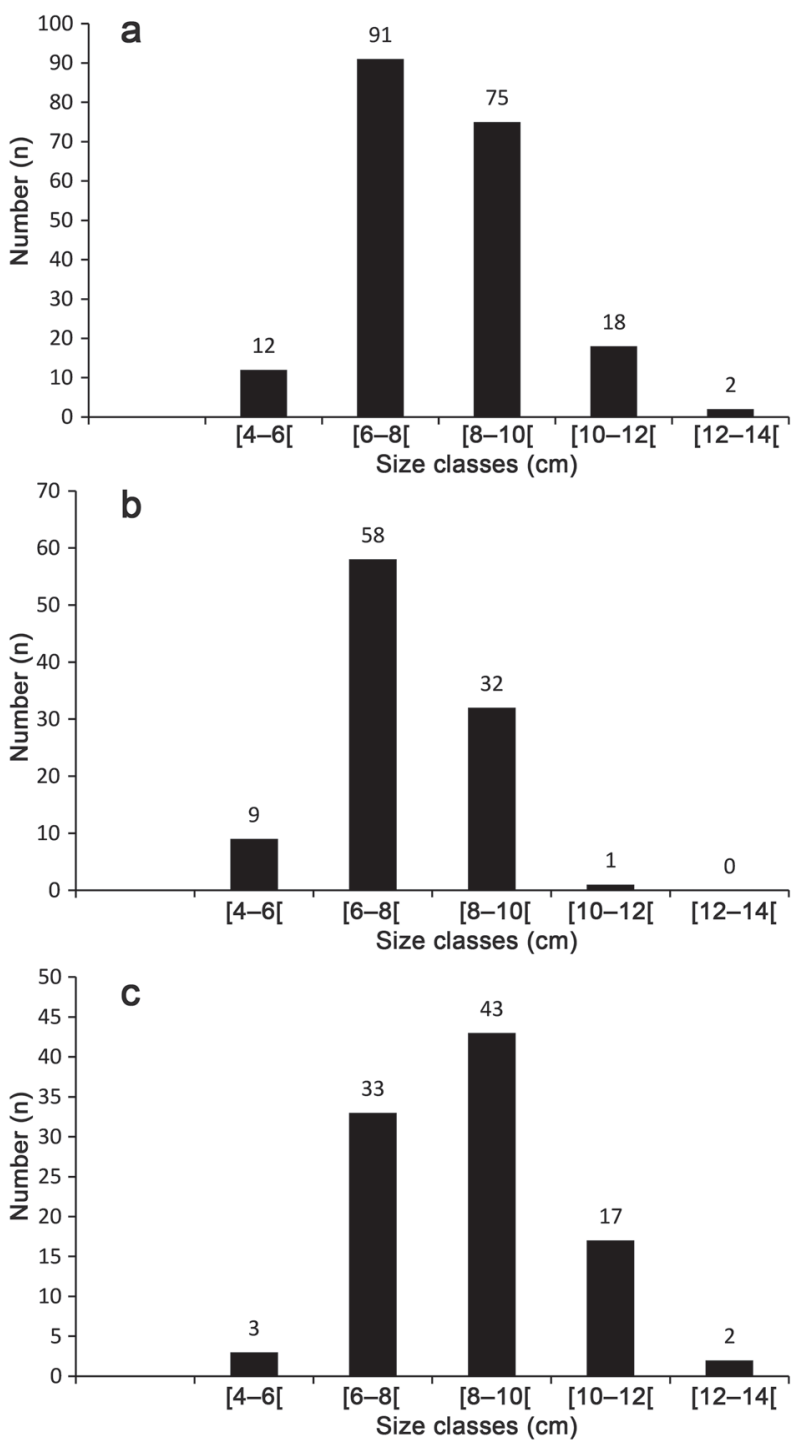

Figure 3. Size classes' structure of the examined specimens of Salaria fluviatilis. a: Both sexes; b: Females; c: Males.

were poorly represented (Figure $4 a, b, c)$. The results obtained show that the populations of $S$. fluviatilis from the studied region were composed mainly of young specimens.

\section{Sex ratio}

In our study region, the populations of $S$. fluviatilis showed balance in sex ratio $(\mathrm{SR}=0.98)$, with a femininity rate of $50.5 \%$ and masculinity rate of $49.5 \%$. The Chi-square test $\left(\chi^{2}\right)$ showed no significant difference between femininity and masculinity rates $(p>0.05)$ (Table 2).

Concerning evolution of sex ratio according to size classes, the Chi-square test $\left(\chi^{2}\right)$ showed significant differences $(p<0.05)$ between femininity and masculinity rates, except for specimens of size class [8-10 [where no significant differences $(p>0.05)]$ were noted. Therefore, 

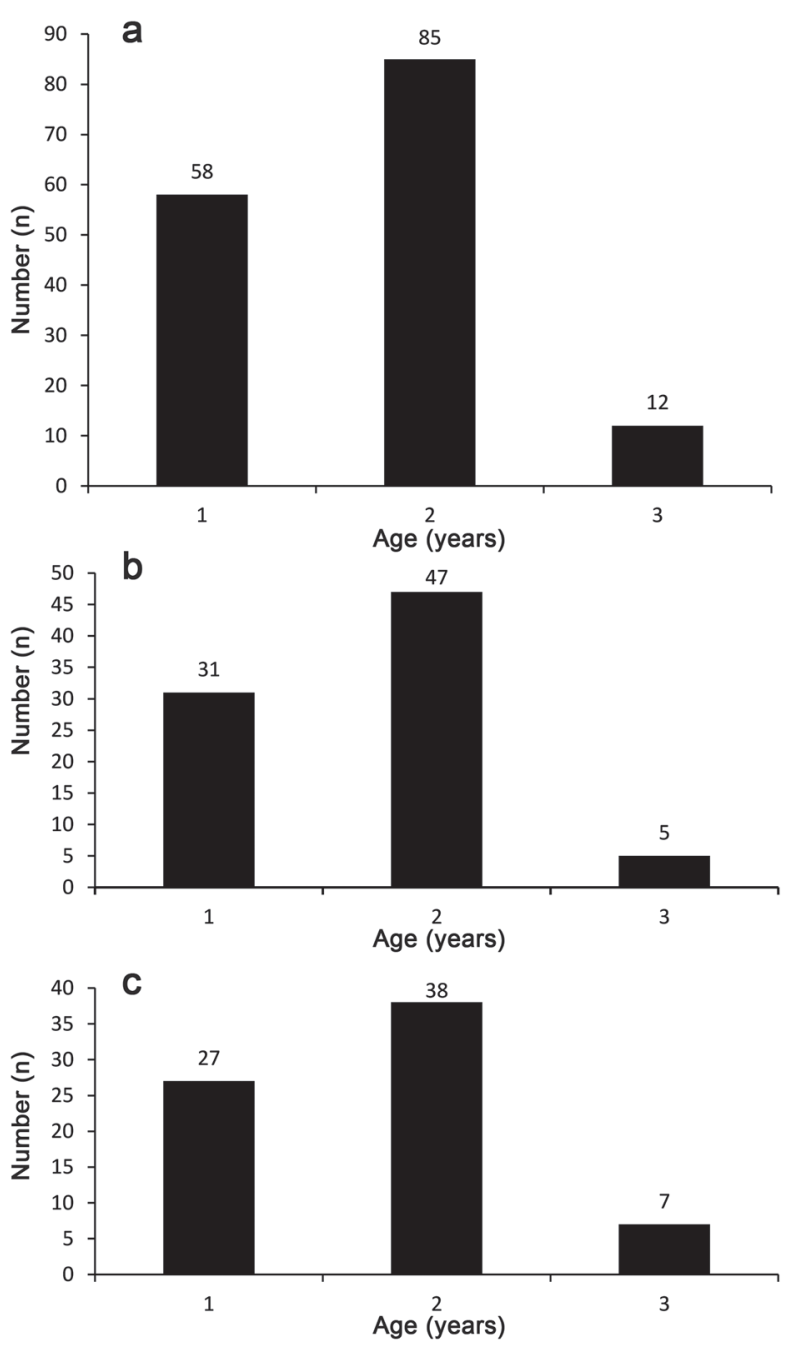

Figure 4. Age classes' structure of the examined specimens of Salaria fluviatilis. a: Both sexes; b: Females; c: Males.

Table 2. Sex- ratio of Salaria fluviatilis in the study region.

\begin{tabular}{|l|c|c|}
\hline & Number of fish & Sex-ratio (\%) \\
\hline Male specimens & 98 & 49.5 \\
\hline Female specimens & 100 & 50.5 \\
\hline Total & 198 & 100 \\
\hline
\end{tabular}

sex ratio was in favour of females $<8 \mathrm{~cm}$ and males $\geq$ $10 \mathrm{~cm}$ (Figure 5a). Our results also show no significant differences $(p>0.05)$ between femininity and masculinity rates in different age classes (Figure $5 b$ ).

\section{Size-weight relationship}

The size-weight relationship was determined for the total population, for males and for females. The studied length-weight relationships were very highly significant $(p>0.001)$. The correlation coefficient $r$ was close to 1 (values ranged between 0.966 and 0.985 ) which confirms that the total weight (TW) was strongly positively correlated with the total length (TL) in both sexes (Figure 6a, b, c).
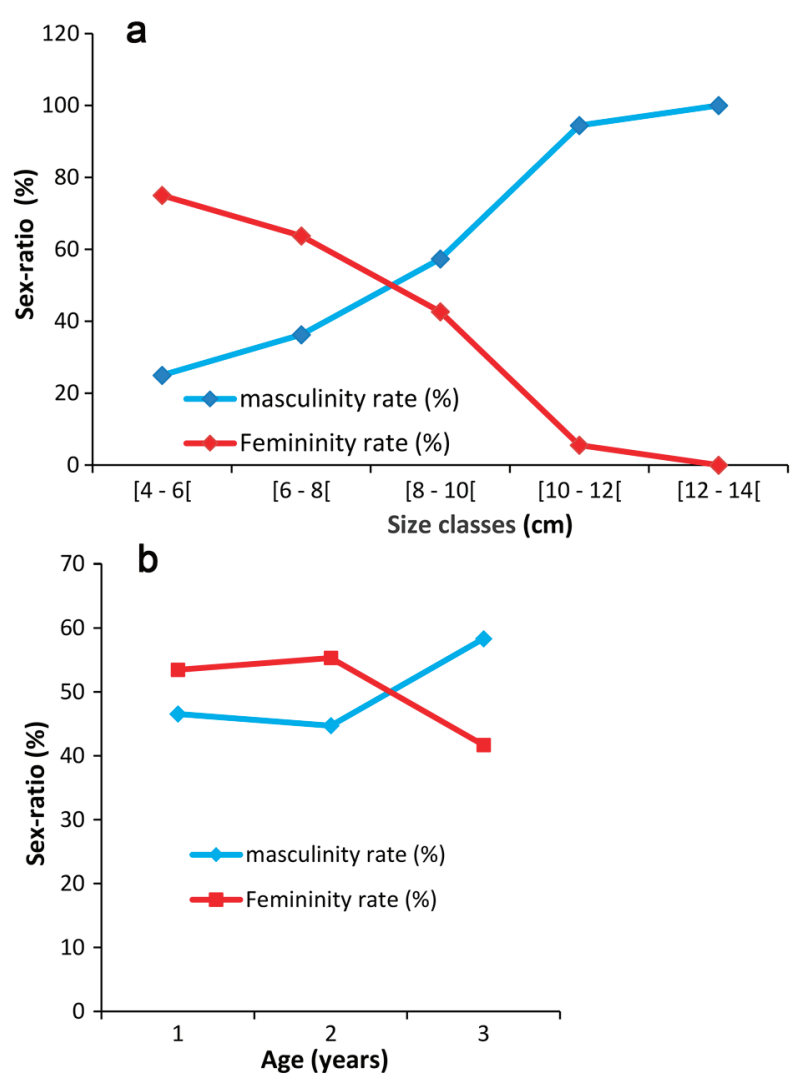

Figure 5. Evolution of the sex ratio of Salaria fluviatilis in the Kabylie region. a: according to size classes; b: according to age classes.

Student's $t$-test at $\alpha=0.05$ shows greater values of observed $t\left(t_{\text {obs }}\right)$ compared to those of theoretical $t\left(t_{\text {the }}\right)$. These results show two types of growth in S. fluviatilis from Kabylie region: a negative allometric growth for females $(b=2.782)$ and a positive allometric growth for males and for both sexes combined $(b=3.195)$ (Table 3).

Thus, males grew more in weight than in length. In contrast, females grew more in length than in weight. This is due to the fact that females were probably sexually mature, so the energy reserved for their gonadal activity probably came from body weight, i.e. reorientation of energy reserves towards gonadal activity occurred.

\section{Linear growth parameters}

The results obtained based on the direct estimation of age allowed us to distinguish 3 groups of specimens: 1 -year-old (male mean size $=6.63 \pm 0.69$; female mean size $=6.28 \pm 0.90$ ), 2-year-old (male mean size $=8.69$ \pm 0.79 ; female mean size $=8.11 \pm 0.55)$, and 3 -yearold (male mean size $=11.62 \pm 0.70$; female mean size $=9.83 \pm 0.39$ ).

This direct age-length key does not give good results of growth parameters (biased parameters, particularly for $\mathrm{L}_{\infty}$, where $\mathrm{TL}_{\max }>\mathrm{L}_{\infty}$, although we use FISHPARM and 
Table 3. Estimated parameters of the size-weight relationship of Salaria fluviatilis.

\begin{tabular}{|l|c|c|c|c|c|c|l|}
\hline \multicolumn{1}{|c|}{ Sex } & $n$ & $* a$ & $* b$ & $*_{r}$ & $t_{\text {obs }}$ & $t_{\text {the }}$ & Growth \\
\hline Total specimens & 198 & $4,767.10^{-5}$ & 3.195 & 0.984 & 4.931 & 1.645 & Positive allometry \\
\hline Females & 100 & $2,88.10^{-4}$ & 2.782 & 0.966 & 2.908 & 1.660 & Negative allometry \\
\hline Males & 98 & $4,813.10^{-5}$ & 3.195 & 0.985 & 3.625 & 1.664 & Positive allometry \\
\hline
\end{tabular}

*FISHPARM parameters. $a$ : perception; $b$ : allometric coefficient; $r$ : correlation coefficient; $t_{o b s}$ : observed $t ; t_{\text {the: }}$ theoretical $t$.
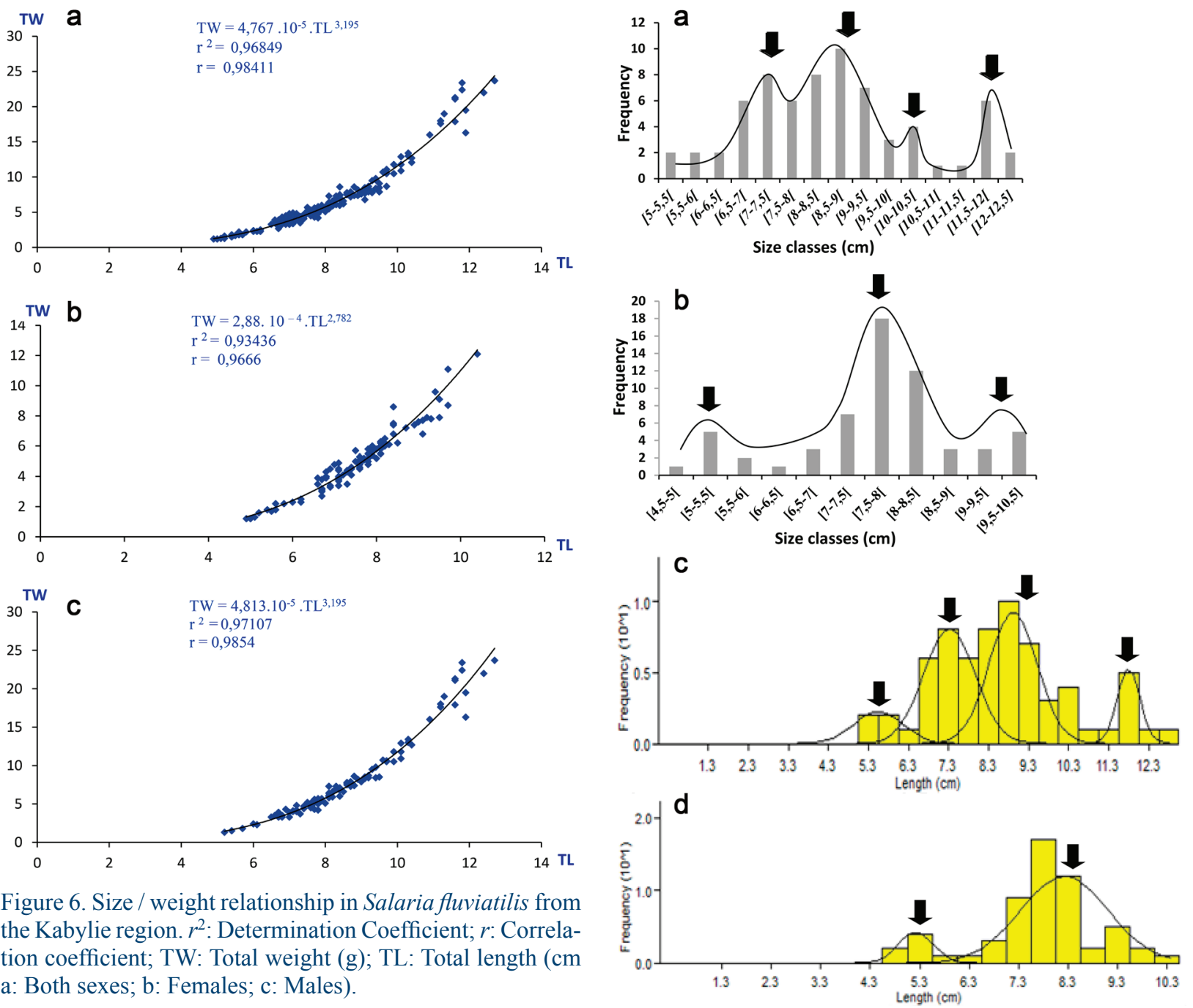

Figure 6. Size / weight relationship in Salaria fluviatilis from the Kabylie region. $r^{2}$ : Determination Coefficient; $r$ : Correlation coefficient; TW: Total weight (g); TL: Total length (cm a: Both sexes; b: Females; c: Males).

FISAT software) (Table 5). This is why we alternatively used indirect methods. The estimated age-length key for both sexes based on the size frequency distribution showed results similar to those obtained by the two indirect methods used: D'Arcy Thompson's (1948) (Figure 7 a, b and Table 3) and Bhattacharya's (1967) (Figure $7 \mathrm{c}, \mathrm{d}$ and Table 4).

Males represent 4 groups of size frequency ( 4 cohorts) and therefore 4 age classes, while females represent 2 (Bhattacharya) or 3 (D'Arcy Thompson) age classes.

The growth parameters obtained from direct methods and checked using FISHPARM and FISAT software are neither reasonable nor logical $\left(\mathrm{TL}_{\max }>\mathrm{L}_{\infty}\right)$ for either sex. The indirect methods based on the size frequency

Figure 7. Polymodal frequency distribution (see black arrows) for males (a) and females (b) (D'Arcy Thompson 1948) and for males (c) and females (d) (Bhattacharya 1967).

distribution (size structure) give us better and more acceptable parameters (Von Bertalanffy 1938) (Table 5). We opted for Bhattacharya's method (age-length key), because it is the method most frequently used by researchers (it gives better results). Growth parameters were more important in male specimens $(\mathrm{L} \infty=14.32$, $\left.\mathrm{K}=0.37, \mathrm{t}_{0}=-0.056\right)$ than in female specimens $(\mathrm{L} \infty=$ $12.37, \mathrm{~K}=0.54, \mathrm{t}_{0}=-0.001$ ), except for the growth rate (K) where the values were close (Table 5).

The length-growth curves of $S$. fluviatilis show a relatively fast growth during the first year of life, and then 
Table 4. Age-length keys for male and female of Salaria fluviatilis (Indirect method).

\begin{tabular}{|l|l|c|c|c|c|}
\hline \multicolumn{1}{|c|}{ Applied methods } & \multicolumn{1}{c|}{ Age (year) } & 1 & 2 & 3 & 4 \\
\hline \multirow{2}{*}{$\begin{array}{l}\text { Method of D'Arcy Thompson (1948) } \\
\text { (Size frequency distribution) }\end{array}$} & Males length $(\mathrm{cm})$ & $7.25^{*}$ & 8.75 & 10.25 & 11.75 \\
\cline { 2 - 6 } & Females length $(\mathrm{cm})$ & $5.25^{*}$ & 7.75 & 10 & $/$ \\
\hline $\begin{array}{l}\text { Method of Bhattacharya (1967) } \\
\text { (Size frequency distribution) }\end{array}$ & Males length $(\mathrm{cm})$ & $5.50 \pm 0.6$ & $7.27 \pm 0.6$ & $8.86 \pm 0.6$ & $11.75 \pm 0.3$ \\
\cline { 2 - 6 } & Females length $(\mathrm{cm})$ & $5.17 \pm 0.3$ & $8.17 \pm 0.8$ & $/$ & $/$ \\
\hline
\end{tabular}

*: First modal size.

Table 5. Growth parameters and performance index of Salaria fluviatilis in the study region.

\begin{tabular}{|l|l|c|c|c|c|c|c|}
\hline \multicolumn{2}{|c|}{ Estimated linear growth parameters } & Sexes & $\mathrm{L}_{\max }$ & $\mathrm{L}_{\infty}$ & $\mathrm{K}$ & $t_{0}$ & $\Phi(\mathrm{cm} /$ year $)$ \\
\hline \multirow{3}{*}{ Direct methods } & FISHPARM software & Female & 10.4 & $7.32^{*}$ & 0.1 & -8.53 & 0.73 \\
\cline { 2 - 9 } & \multirow{2}{*}{ FISAT software } & Male & 12.7 & $11.64 *$ & 0.54 & -8.02 & 1.86 \\
\cline { 2 - 9 } & & Female & 10.4 & $7.90^{*}$ & 2.16 & 0.00 & 2.13 \\
\hline \multirow{2}{*}{ Indirect methods } & FISAT software Von Bertalanffy (1938) & Female & 10.4 & $\mathbf{1 2 . 3 7}$ & $\mathbf{0 . 5 4}$ & $\mathbf{- 0 . 0 0 1}$ & $\mathbf{1 . 9 2}$ \\
\cline { 2 - 9 } & & Male & 12.7 & 14.32 & $\mathbf{0 . 3 7}$ & $\mathbf{- 0 . 0 5 6}$ & 1.88 \\
\hline
\end{tabular}

*: Unreasonable values of $\mathrm{L} \infty\left(\mathrm{TL}_{\max }>\mathrm{L}_{\infty}\right)$; $\Phi$ : Performance index.

show a gradual slowdown from the second year, which is true for both sexes (Figure 8a, b). Our results show a higher growth speed in females than in males. The performance index $(\Phi)$ of female $(1.92 \mathrm{~cm} /$ year $)$ and male specimens $(1.88 \mathrm{~cm} /$ year $)$ is practically similar (Table 5).

The condition coefficient (Fulton's K) of S. fluviatilis demonstrates low fluctuation throughout the year. The monthly mean values show similar evolution in both sexes and in the whole population $(0.010,0.0097$ and 0.0099 , respectively; Figure 9a). Very high variations $(p<0.001)$ (Student's $t$-test) were recorded in Fulton's $\mathrm{K}$ between males and females of this fish species. Our results also show that this index has a tendency to increase slightly during the first two years, and then it decreases gradually during the third year for both sexes (Figure 9b). This index shows small variations according to size classes for male and female specimens with a tendency to decrease slightly with age (Figure $9 c)$. Very high differences $(p<0.001)$ (ANOVA) were recorded between the mean $\mathrm{K}$ values of different age classes and size classes.

\section{Reproduction period of $S$. fluviatilis from the study region}

Our results show an increase of the gonadosomatic index (GSI) from April to June. This index decreased in July and reached its minimum value in mid-August. In the study region, the spawning period of S. fluviatilis occurred between April and July (4 months) (Figure $10 a, b, c)$.

The hepatosomatic index (HSI) and gonadosomatic
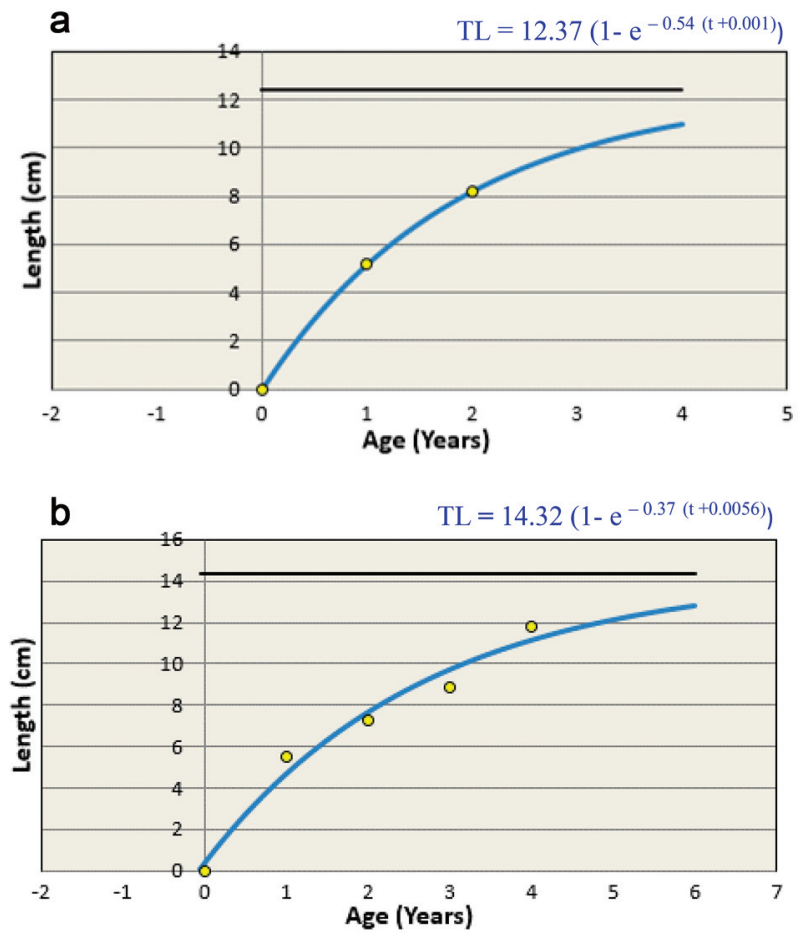

Figure 8. Linear growth curve (Von Bertalanffy model) of Salaria fluviatilis from the Kabylie region. a: Females; b: Males; TL: Total length (cm).

index (GSI) followed the same pattern. Their maximum value coincided with the reproductive period. These results indicated clearly that liver energy reserves were not used at all in the reproduction of this fish. The condition index (Fulton's K) showed low fluctuations. However, this index increased just before the reproduction period, particularly in March, and then decreased slightly dur- 

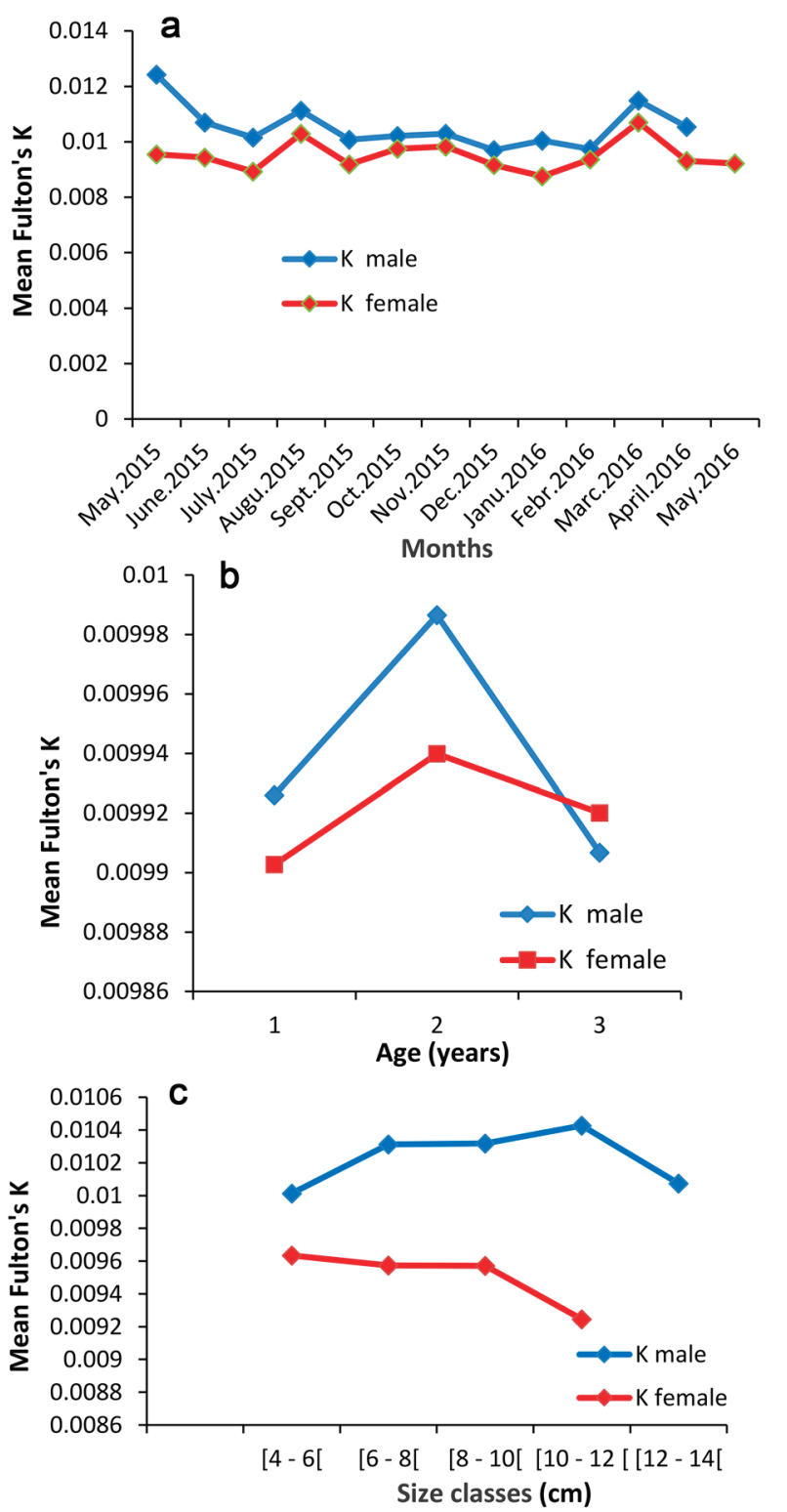

Figure 9. Evolution of mean Fulton's K of males and females of Salaria fluviatilis from the Kabylie region. a: According to the months; $\mathrm{b}$ : According to the age classes; $\mathrm{c}$ : According to the size classes.

ing the breeding season (April-May), which means that muscular reserves probably supported the reproduction of $S$. fluviatilis.

\section{DISCUSSION}

Our biological study conducted on 198 specimens of $S$. fluviatilis shows results similar to those recorded by Ilhan and Ruşen Ustaoğlu (2013) on S. fluviatilis from Turkey, where these authors reported lengths ranging from 2.0 to $12.9 \mathrm{~cm}$ and weights ranging from 0.10 to $33.82 \mathrm{~g}$. The maximum total length $(12.7 \mathrm{~cm})$ we recorded is lower than that found by Laporte et al. (2013) in the Bravona River in Corsica $(15.4 \mathrm{~cm})$. These
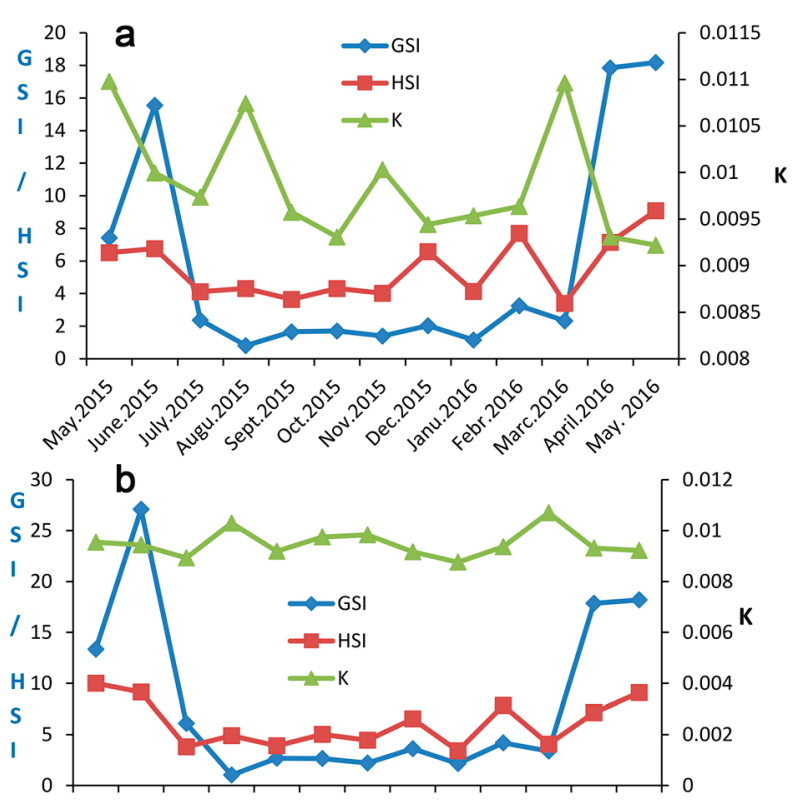

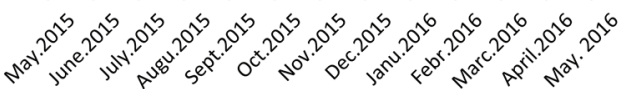

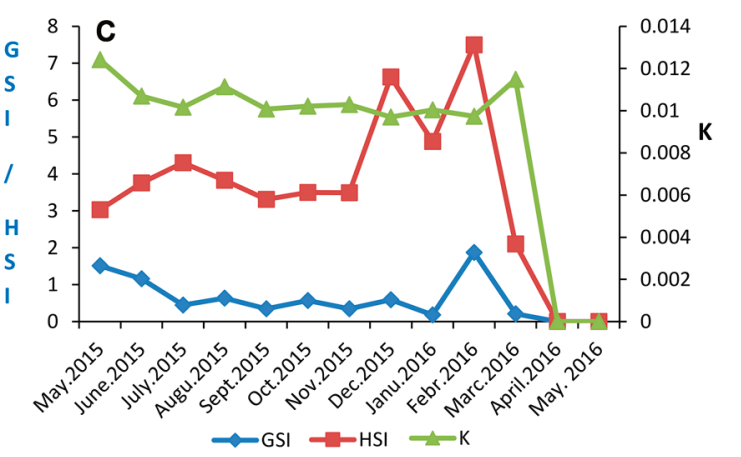

Figure 10. Monthly variation of gonado-somatic index (GSI), hepato-somatic index (HSI) and Fulton's K of Salaria fluviatilis from the Kabylie region. a: Both sexes; b: Females; c: Males.

authors confirmed that the island rivers of Corsica are home to larger individuals compared to those dwelling in continental rivers (Table 6).

The demographic structure of $S$. fluviatilis reveals that specimens less than $8 \mathrm{~cm}$ in size are best represented in females, whereas specimens with a total length greater than $8 \mathrm{~cm}$ dominate in males.

In our study region, the maximum age reached by $S$. fluviatilis is 3 years with the dominance of two-year-old specimens, which may be related to sampling. In fact, young fish have a gregarious and pelagic behaviour which facilitates their capture, while older ones are territorial and benthic and, therefore, more difficult to capture. Our results corroborate those reported by Vinyoles and De Sostoa (2007) who reported four-yearold specimens in north-eastern Spain, but always with the predominance of young specimens (Table 6).

The sex ratio of $S$. fluviatilis specimens in the area we 
examined was found to be in balance. Our results are different from those reported in Lake Kournas in Greece, Lake Garda in Italy and Fango River in Corsica (Neat et al. 2003) and in the Ceyhan River in Turkey (Alp and Kara 2007). All these authors reported highly feminized populations in their respective studied regions. However, their data differ from those found by Vinyoles and De Sostoa (2007) in north-eastern Spain, where they reported a sex ratio in favour of males, especially during the spawning period (Table 6).

According to Côté et al. (1999), differences in the sex ratio of $S$. fluviatilis may be due to behaviour (males protect eggs). In fact, females lay eggs on the underside of stones, and these eggs are protected against predators by males. Consequently, males are more exposed to predation than females. The size-weight relationships in S. fluviatilis are very highly significant $(p>0.001)$. Our results showed a positive allometry in male specimens and a negative allometry in female specimens. These results are inconsistent with those found by Ilhan and Ruşen Ustaoğlu (2013) in Turkey, who reported a highly significant correlation, but with isometric growth (Table 6).

The direct method used in the present study did not give good results of estimating linear growth parameters of S. fluviatilis for the following reasons: (i) a very low number of 3-year-old specimens, particularly in females; (ii) the dominance of 2-year-old specimens of both sexes in our samples (maybe related to the selection of the fishing gear used (hawk net); and (iii) reading errors (differences in the estimated age) which led to elimination of $30 \%$ of otoliths. All these factors may introduce bias to the estimated growth parameters; therefore, we alternatively applied indirect methods.
Analysis of the growth curves of $S$. fluviatilis shows that growth is faster in young specimens compared to older ones. Growth parameters are higher in male specimens than in female specimens (males are larger and longer than females), and length growth in females is faster than in males (see the obtained $\mathrm{K}$ ). Our results differ from those found by Vinyoles and De Sostoa (2007) in north-eastern Spain where these authors reported similar growth patterns for both sexes of $S$. fluviatilis. The growth performance index $(\Phi)$ calculated for both sexes of this fish species revealed similar values, confirming thus the same growth potential (Table 4). This similarity is most probably related to the life history traits of both sexes.

The monthly evolution of the gonadosomatic index (GSI) showed that S. fluviatilis populations are characterized by a fairly long reproductive period. Indeed, it spreads from April until July. Gonad development begins in April, peaks in June and declines progressively during the month of July until the beginning of August. Therefore, the spawning period of S. fluviatilis occurs between April and July.

Our results differ slightly from those reported by Lengkeek and Didderen (2006) in Corsica and by Freeman et al. (1990) and Vinyoles and De Sostoa (2007) in Spain, who reported the breeding season from May to August. However, in Lake Kinneret in Israel, this species breeds throughout the year but with a more intense period between March and July (Gasith and Goren 2009). According to these authors, a long breeding season in this lake is probably associated with high temperatures ranging from 14 to $30^{\circ} \mathrm{C}$. Several authors have pointed out that the breeding season is dependent on water temperatures. Neat et al. (2003) found that in Lake Kournas

Table 6. Some biological parameters of Salaria fluviatilis from the Mediterranean Sea.

\begin{tabular}{|l|l|l|l|}
\hline \multicolumn{1}{|c|}{ Parameters } & \multicolumn{1}{|c|}{ Values } & \multicolumn{1}{c|}{ Regions } \\
\hline Maximum length & $\begin{array}{l}12.9 \mathrm{~cm} \\
15.4 \mathrm{~cm} \\
12.7 \mathrm{~cm}\end{array}$ & $\begin{array}{l}\text { Turkey } \\
\text { Corsica (France) Kabylie } \\
\text { (Algeria) }\end{array}$ & $\begin{array}{l}\text { Ilhan and Ruşen Ustaoğlu (2013) } \\
\text { Laporte et al. (2013) } \\
\text { Present study }\end{array}$ \\
\hline Maximum weight & $\begin{array}{l}33.82 \mathrm{~g} \\
23.7 \mathrm{~g}\end{array}$ & $\begin{array}{l}\text { Turkey } \\
\text { Kabylie (Algeria) }\end{array}$ & $\begin{array}{l}\text { Ilhan and Ruşen Ustaoğlu (2013) } \\
\text { Present study }\end{array}$ \\
\hline Maximum age & $\begin{array}{l}\text { 4 years } \\
\text { 3 years }\end{array}$ & $\begin{array}{l}\text { Spain } \\
\text { Kabylie (Algeria) }\end{array}$ & $\begin{array}{l}\text { Vinyoles and De Sostoa (2007) } \\
\text { Present study }\end{array}$ \\
\hline Size/weight relationship & $\begin{array}{l}\text { Isometric growth } \\
\text { Allometric growth (positive for } \\
\text { males) (negative for females) }\end{array}$ & $\begin{array}{l}\text { Turkey } \\
\text { Kabylie (Algeria) }\end{array}$ & $\begin{array}{l}\text { Ilhan and Ruşen Ustaoğlu (2013) } \\
\text { Present study }\end{array}$ \\
\hline Sex-ratio & $\begin{array}{l}\text { In favor of males } \\
\text { In favor of females } \\
\text { In favor of females } \\
\text { In balance }\end{array}$ & $\begin{array}{l}\text { Spain } \\
\text { Greece, Italy and Corsica } \\
\text { Turkey } \\
\text { Kabylie (Algeria) }\end{array}$ & $\begin{array}{l}\text { Vinyoles and De Sostoa (2007) } \\
\text { Alp and Kara (2007) } \\
\text { Present study }\end{array}$ \\
\hline Reproduction period & $\begin{array}{l}\text { May-August } \\
\text { May-August } \\
\text { March-July } \\
\text { March-July } \\
\text { April-July }\end{array}$ & $\begin{array}{l}\text { Spain } \\
\text { Spain } \\
\text { Corsica (France) } \\
\text { Israel } \\
\text { Kabylie (Algeria) }\end{array}$ & $\begin{array}{l}\text { Vinyoles and De Sostoa (2007) } \\
\text { Lengkeek and Didderen (2006) } \\
\text { Gasith and Goren (2009) } \\
\text { Present study }\end{array}$ \\
\hline
\end{tabular}


(Greece), Lake Garda (Italy) and Fango River (Corsica) this species spawned at variable temperatures between 18 and $21^{\circ} \mathrm{C}$.

A similar evolution of the gonadosomatic index (GSI) and hepatosomatic index (HSI) was observed throughout the study period; however, a relative increase in Fulton's $\mathrm{K}$ values was noted before reproduction. These results show that liver reserves are not allocated to reproduction; in contrast, muscle stores probably contribute to maintaining and supporting the reproductive activity of this species. Therefore, it can be suggested that energy for reproduction comes from the active diet of this species just before the reproductive period.

\section{CONCLUSION}

The following new data on the biology of Salaria fluviatilis from Kabylie region are recorded: populations of this species are dominated by two-year-old specimens; sex ratio is in balance; a close positive relationship between total weight and total length in both sexes was recorded with a positive allometry in males and a negative allometry in females; this fish exhibits fast growth during its first year of life; growth parameters are higher in males than in females; the performance index $(\Phi)$ of S. fluviatilis in the study rivers is similar, which confirms the same growth potential in both sexes; the monthly evolution of gonado-somatic, hepato-somatic and Fulton's K indexes revealed that the breeding period of S. fluviatilis occurs between April and July and energy reserves devoted for reproduction most probably come from muscles rather than from the liver.

The situation of $S$. fluviatilis in Kabylie region (northern Algeria) is actually very worrying, because despite the existence of fairly dense river systems, its populations are limited to a few rivers. This fish species is restricted to relatively conserved stations. Environmental factors, such as temperature, food availability, current and water quality, are probably favourable for this fish in the study region. This is confirmed by a good condition of S. fluviatilis specimens and also by the rapid growth and early maturity during the first two years of their life. No specimen was caught in perturbed stations, which confirms that $S$. fluviatilis is an excellent bioindicator of the quality of water in which it evolves. Due to its ecological requirements, this species is now endangered because of several constraints (drought, pollution, habitat degradation, etc.). The studied biological traits of this fish give us some interesting and necessary scientific data for its conservation. However, other studies such as trophic ecology and population dynamics using suitable sampling method (electric fishing) are needed. For its conservation, studies focused on the evolution of S. fluviatilis populations and their habitats must be carried out in the study region.

\section{ACKNOWLEDGMENT}

We warmly thank the reviewers for their corrections and evaluation of the manuscript, as well as all those who participated in different sampling campaigns, in particular Bachir Seddik and Dr Cheli Madjid who were very useful during this study. We also thank Houcine Abbaci for his precious help in preparing the photos for this manuscript, without forgetting Smail Adjrad and Karim Bensaid for their help with statistical analysis.

\section{REFERENCES}

Almada, V. C., R. F. Oliveira, E. J. Goncalves, A. J. Almeida, R. S. Santos, and P. Wirtz.2001. Patterns of diversity of the north-eastern Atlantic blenniid fish fauna (Pisces: Blenniidae). Global Ecology and Biogeography 10: 411-422.

Almada, F., V. C. Almada, T. Guillemaud, and P. Wirtz. 2005. Phylogenetic relationships of the north-eastern Atlantic and Mediterranean blenniids. Biological Journal of the Linnaean Society 86: 283-295.

Alp, A., and C. Kara. 2007. Distribution Pattern and Morphological Differences between the Sexes of River Blenny, Salaria fluviatilis (Asso, 1801), in the Ceyhan River Basin, Turkey. Turkish journal of zoology 31: 113-120.

Anonymous. 1980. Land and forest inventory study in Northern Algeria: Bejaia Department. General report of the national office of studies for rural development (B.N.E.D.E.R): 205 pp.

Aparicio, E., M. J. Vargas, J. M. Olmo, and A. De Sostoa. 2000. Decline of native freshwater fishes in a Mediterranean watershed on the Iberian Peninsula: a quantitative assessment. Environmental Biology of Fish 59: 11-19.

Azeroual, A. 2003. Monograph of the Morocco inland waters fishes. Systematics, distribution and ecology. Doctoral thesis. Mohamed V. Morocco University: Agdal, 194 pp.

Bacha, M., and R. Amara. 2007. The fishes of the continental waters of Algeria. Study of the Soummam ichthyofauna. Cybium 31 (3): 351-358

Balik, S. 1995. Freshwater fish in Anatolia, Turkey. Biological Conservation 72: 213-223.

Bhattacharya, C. G. 1967. A simple method of resolution of a distribution into gaussian components. Biometrics 23 (1): 115-135.

Bianco, P. G. 1995. Mediterranean endemic fresh-water fishes of Italy. Biological Conservation 72: 159-170. 
Bougis, P. 1952. Biometric research on red mullet (Mullus barbatus L. and Mullus surmuletus L.). Archives of Experimental and General Zoology 89: 59-174

Briggs, J. C. 2010. A plethora of blennies. Environmental Biology of Fish 87: 89-92.

Changeux, T., and D. Pont. 1995. Current status of the riverine fishes of the French Mediterranean basin. Biological Conservation 72: 137-158.

Côté, I. M., D. Vinyoles, D. J. Reynolds, I. Doadrio, and A. Percides. 1999. Potential impacts of gravel extraction on Spanish populations of river blennies Salaria fluviatilis (Pisces, Blenniidae). Biological Conservation 87: 359-367.

D'Arcy Thompson. 1948. On growth and form. Cambridge University Press.

Dagnelie, P. 1975. Statistical theories and methods. Agronomic applications 2: 378-451. Gembloux: Agronomic Press.

Doadrio, I. 2001. Atlas and Red Book of Continental Spain Fishes . Directorate General for the Conservation of Nature National Museum of Natural Sciences, Madrid, Spain, $376 \mathrm{pp}$.

Doadrio, I., S. Perea, and A. Yahyaoui. 2011. Morphological and molecular analyses of Freshwater blennids: A new species of the genus Salaria Forsskal, 1775 (Actinopterygii, Blennidae) in Morocco. Graellsia 67 (2): 151-173. https://doi.org/10.3989/graellsia.2011. v67.042

Economidis, P. S. 1995. Endangered freshwater fishes of Greece. Biological conservation 72: 201-211.

Elvira, B. 1995a. Conservation status of endemic freshwater fish in Spain. Biological Conservation 72: 129-136.

Elvira, B. 1995b. Native and exotic freshwater fishes in Spanish river basins. Freshwater Biology 33: 103-108.

Ferrito, V., and C. Tigano. 1996. Decline of Aphanius fasciatus (Cyprinodontidae) and Salaria fluviatilis (Blenniidae) populations in freshwater of eastern Sicily. Ichthyological Exploration of Freshwaters 7: 181-184.

Freeman, M. C., D. Vinolas, G. D. Grossman, and A. De Sostoa. 1990. Microhabitat use by Blennius fluviatilis in the Rio Matarrana, Spain. Freshwater Biology 24: 335-345.

Gasith, A., and M. Goren. 2009. Habitat availability, reproduction and population dynamics of the fresh water blenny Salaria fluviatilis (Asso, 1801) in lake Kinneret, Israel. Electronic Journal of Ichthyology 2: 34-46.

Gayanilo, Jr F.C., Sparre, and D.Paugy.2005. FAO-ICLARM Stock Assessment Tools II (FISAT II). Revised version. User manual. FAO Computer series 8: 190. Fisheries. Revised version. FAO: Rome.

Gharred, T., and M. H. Ktari. 2001. Interspecific polymorphism of Blenniidae (Teleost fish) of the Tunisian coasts. Bulletin of the National Institute of Marine Sci- ences and Technologies - Salammbô 28: 34-53.

Gil, F., C. Faria, and V. C. Almada. 2010. An Efficient Technique for the Captive Breeding of an Endangered Freshwater Fish Salaria fluviatilis (Pisces: Blenniidae), with a description of its ontogeny. Journal of the world aquaculture society 41: 49-56.

Hernández, R., R. T. Lacomba, Y. N. Uviñas, and R. Oltra. 2000. Distribution pattern of the river blennies in the Júcar river basin (eastern Spain). Journal of Fish Biology 57: 250-254. https://doi.org/10.1111/j.10958649.2000.tb00790.x

Ilhan, A., and M. Ruşen Ustaoğlu. 2013. The length-weight relationship of freshwater blenny, Salaria fluviatilis (Asso, 1801) in 7 drainage basin of Turkey. Edge Journal of Fisheries and Aquatic Sciences 30 (1): 41-43 (2013). https://doi.org/10.12714/egejfas.

Kara, H. M. 2011. Freshwater fish diversity in Algeria with emphasis on alien species. European Journal of Wildlife Research 58: 243-253. https://doi.org/10.1007/s10344 - 011-0570-6

Kartas, F., and J. P. Quignard. 1984. The fertility of teleost fish. Collection of marine biology. Paris: Ed. Masson, 121 pp.

Keith, P., and J. Allardi. 2001. Atlas of French freshwater fish. National Museum of Natural History, Paris, 392 pp. (Natural heritage, 47 pp.).

Keith, P., H. Persat, E. Feunteun, and J. Allardi. 2011 France freshwater fish. National Museum of Natural History (Inventories \& biodiversity 1: 552). Paris: Biotope, Mèze.

Knight, W. 1968. Asymptotic growth: an example of non sense disguised as mathematics. Journal of the Fisheries Research Board of Canada 25 (6): 1303-1307.

Kottelat, M. 2004. Salaria economidisi, a new species of freshwater fish from Lake Trichonis, Greece, with comments on variation in S. fuviatilis (Teleostei: Blenniidae). Revue Suisse de Zoologie 111: 121-137.

Kottelat, M., and J. Freyhof. 2007. Handbook of the European Freshwater Fishes. Cornol: Switzerland and Freyhof. Berlin: Allemagne, 646 pp. Publications Kottelat.

Laporte, M., and P. Magnan. 2010. Bibliographic research and preliminary study of the factors which affect the abundance of the fluvial blenny, Salaria fluviatilis (Asso, 1801), in various coastal rivers of Corsica. Report from the Regional Directorate for the Environment, Planning and Housing (DREAL) of Corsica: 25 pp.

Laporte, M., P. Magnan, A. Bertolo, and P. Berrebi. 2011. The fluvial blenny (Salaria fluviatilis (Asso, 1801) as a potential bioindicator of the quality of aquatic environments Bulletin of the Society of Historical and Natural Sciences of Corsica BSSHNC: 734-735.

Laporte, M., J. Mattei, P. Perret, B. Roche, D. Vinyoles, M. Goren, M. Bacha, Z. Mourad, I. Pou, Q. Rovira, P. Berrebi, and P. Magnan. 2013. New maximum lengths 
for freshwater blenny (Salaria fluviatilis (Asso, 1801) and length comparison between continental and Island Rivers. Cybium 37: 309-313.

Laporte, M., R. Leblois, A. Coulon, F. Bonhomme, P. Magnan, and P. Berrebi. 2015a. Genetic structure of a vulnerable species, the freshwater blenny (Salaria fluviatilis). Conservation Genetics 16: 571-581.

Laporte, M., P. Berrebi, J. Claude, D. Vinyoles, Q. P. Rovirad, J. C. Raymond, and P. Magnan. 2018. The ecology of sexual dimorphism in size and shape of the freshwater Blenny Salaria fluviatilis. Current Zoology 64 (2): 183-191. https://doi.org/10.1093 /cz /zox043

Le Cren, C. D. 1951. The Length-Weight Relationship and Seasonal Cycle in Gonad Weight and Condition in Perch, Perca fluviatilis. Journal of Animal Ecology 20: 201-219. http://dx.doi.org/10.2307/1540

Lengkeek, W., and K. Didderen. 2006. Breeding cycles and reproductive behaviour in the river blenny Salaria fluviatilis. Journal of Fish Biology 69: 1837-1844.

Lounaci-Daoudi, D., A. Lounaci, and A. Arab. 2016. Freshwater fish fauna of Algeria. The fish fauna of inland waters of Great-Kabylie. Advances in Environmental Biology 10 (12): 74-83.

Mayrat, A. 1970. Allometry and taxonomy. Applied statistics review 18 (4): 47-58.

Micha, J. C. 1973. Study of the fish populations of the Oubangui and temptation to select and adapt some species to the pisciculture pond. Nogent-sur-Marne, France: Technical Center for Tropical Forests, $110 \mathrm{pp}$.

Mrakovcic, M., S. Misetic, and M. Povz. 1995. Status of freshwater fish in Croatian Adriatic river systems. Biological Conservation 72: 179-185.

Neat, F. C., W. Lengkeek, E. P. Westerbeek, B. Laarhoven, and J. J. Videler. 2003. Behavioural and morphological differences between lake and river populations of Salaria fluviatilis. Journal of Fish Biology 63: 374-387. https://doi.org/10.1046/j.1095-8649.2003.00159.x

Pauly, D., and J. L. Munro. 1984. Once more on growth comparison in fish and invertebrates. Fishbyte 2 (1): 21.

Perdices, A., I. Doadrio, I. M. Côté, A. Machordom, P. Economidis, and J. D. Reynolds. 2000. Genetic divergence and origin of mediterranean populations of the river blennie Salaria fluviatilis (Teleostei: Blenniidae). Copeia 3: 723-731.

Persat, H. 2011. Family of Blenniidae. Fluvial blenny, Salaria fluviatilis (Asso, 1801). In Atlas of the France Freshwater Fishes, edited by Keith, P., Persat, H., Feunteun, E., and Allardi, J., 463-465. Mèze, Paris: Biotope Ed. Collection Parthénope \& Scientific publications of the Museum.

Prager, M. H., S. B. Saila, and C. W. Recksiek. 1994. FISHPARM: A Microcomputer program for Parameter Estimation of Nonlinear Models in Fishery Science. National Marine Fisheries Service USA, 23 pp.

Ricker, W. E. 1975. Computation and interpretation of the biological statistics of fish populations. Bulletin of the Fisheries Research Board of Canada 191: 1-382.

Ricker, W. E. 1980. Methods for assessment of fish production in freshwaters. I. B. P. Handbook, Oxford-Edinburgh, Blackwell Scientific Publications 3: 93-123.

Roché, B. 2001. Atlas of Corsican freshwater fish. Regional Directorate for the Environment, Planning and Housing. Bastia, Corsica, 49 pp.

Sutton, S. G., T. P. Bult, and R. Haedrich. 2000. Relationships among fat weight, body weight, water weight and condition factors in wild Atlantic salmon Parr. Transactions of the American fisheries Society 129: 527-538.

Tesch, F. W. 1971. Age and growth. In Methods for assessment of fish production in fresh waters. Oxford (UK): Blackwell Scientific Publications, edited by Ricker W. E., 99-130.

UICN France, MNHN, SFI, and Onema. 2010. The red list of threatened species in France. Chapter Freshwater fish in mainland France. Paris, France, 12 pp.

Vinyoles, D., and A. De Sostoa. 2007. Life-history traits of the endangered river blenny Salaria fluviatilis (Asso) and their implications for conservation. Journal of Fish Biology 70 (4): 1088-1108. https://doi.org/10.1111/ j.1095-8649.2007.01371.x

Vinyoles, D., I. M. Côté, and A. De Sostoa. 2002. Nest orientation patterns in Salaria fluviatilis. Journal of Fish Biology 61: 405-516.

Von Bertalanffy. 1938. A quantitative theory of organic growth. Human Biology 10 (2): 181-213.

Zander, C. D. 1972. Evolution of Blennioidei in the Mediterranean Sea. Review of the Work of the Scientific Institute of Maritime Fisheries 37: 215-221. 